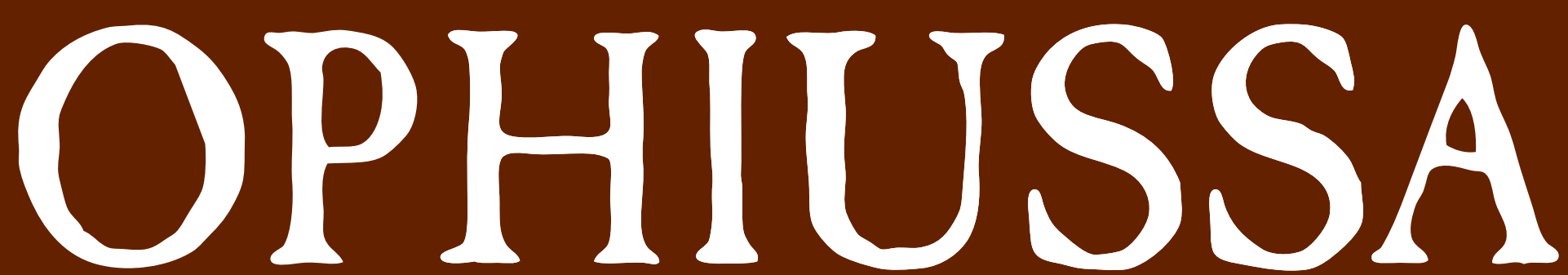
REVISTA DO CENTRO DE ARQUEOLOGIA DA UNIVERSIDADE DE LISBOA

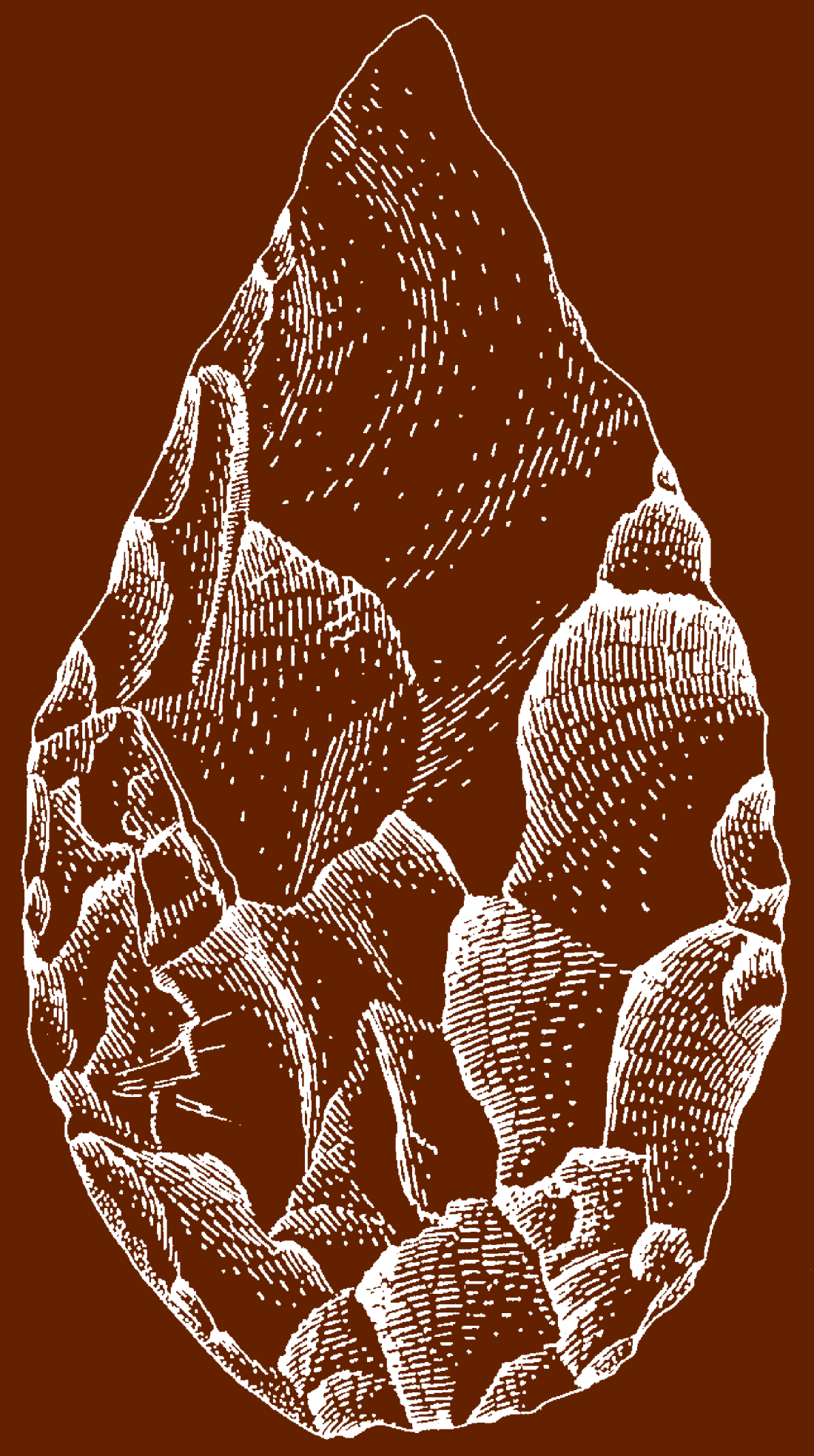

CENTRO DE ARQUEOLOGIA

DA UNIVERSIDADE

DE LISBOA 
RECENSÕES BIBLIOGRÁFICAS 


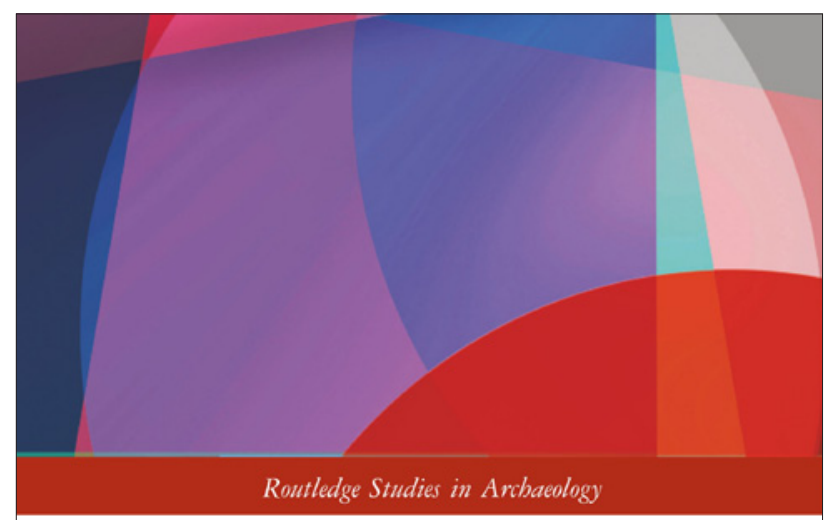

\section{ALTERNATIVE IRON AGES}

\section{SOCIAL THEORY FROM ARCHAEOLOGICAL ANALYSIS}

Edited by

Brais X. Currás and Inés Sastre

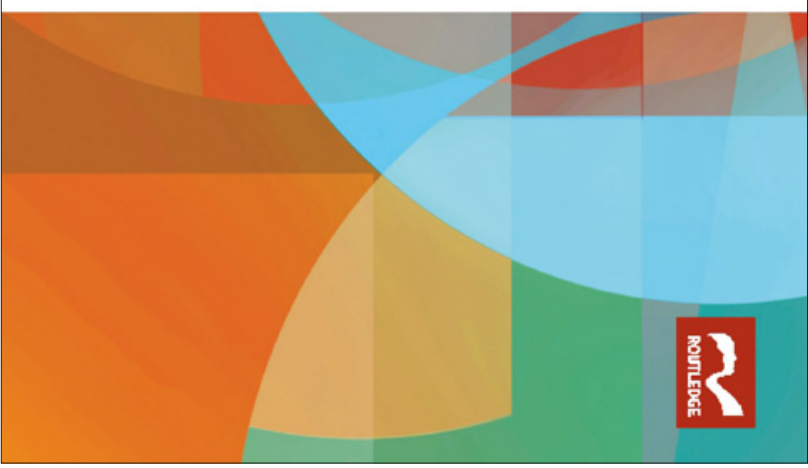

CURRÁS, B. X. - SASTRE, I. (eds.), 2020

Alternative Iron Ages. Social Theory From

Archaeological Analysis

Londres: Routledge. 390 pp. com figuras

[ISBN 9781138541023]

\section{FRANCISCO B. GOMES}

UNIARQ - Centro de Arqueologia da Universidade de Lisboa

Fundação para a Ciência e Tecnologia

ORCID iD: https://orcid.org/0000-0003-0664-6374

franciscojbgomes@gmail.com

https://doi.org/10.51679/ophiussa.2021.94
O estudo das comunidades da Idade do Ferro europeia, frequentemente categorizadas como "proto-históricas", assenta com frequência numa leitura combinada dos dados arqueológicos e dos relatos textuais greco-latinos. Estes últimos, contudo, foram frequentemente sobrevalorizados, particularmente dentro dos modelos histórico-culturalistas cujo legado historiográfico ainda hoje se faz sentir neste domínio da investigação. Apesar do seu contexto, claramente externo e frequentemente enviesado, as fontes escritas foram de facto tomadas como um guião para a leitura do registo arqueológico, cuja diversidade e complexidade foram frequentemente preteridas em favor de modelos esquemáticos compatíveis com o panorama exposto pelos autores greco-latinos.

Nos últimos anos tem-se contudo vindo a produzir uma releitura crítica deste período, assente em dois pilares fundamentais: por um lado, uma crítica de fontes mais sólida, que tem contribuído para situar histórica e ideologicamente as fontes escritas e, dessa forma, repensar e contextualizar o seu potencial informativo; e, por outro lado, uma reapreciação do registo arqueológico, assente, entre outras ferramentas metodológicas, na aplicação de modelos e quadros de leitura de matriz antropológica.

Esta renovação teórica e metodológica tem vindo a saldar-se, em distintas regiões, no desenvolvimento de leituras mais complexas e matizadas sobre o processo histórico das comunidades da Idade do Ferro, e em particular sobre os seus modelos de organização sociopolítica. Com efeito, a imagem de umas comunidades altamente hierarquizadas, dominadas por uma elite guerreira frequentemente encabeçada por um príncipe ou régulo (cf. Arnold - Gibson 1998; Thurston 2010), decalcada de uns relatos textuais historicamente situados, mas que se generalizam à (quase) totalidade da Idade do Ferro, tem vindo a ser questionada e cotejada com outras leituras alternativas.

$\mathrm{O}$ volume Alternative Iron Ages, editado por Brais X. Currás e Inés Sastre, resultante de uma sessão organizada pelos editores no encontro anual da European Association of Archaeologists de 2017, em Maastricht, constitui um verdadeiro marco neste processo de revisão das leituras vigentes sobre a Idade do Ferro europeia. Com efeito, esta obra representa simultaneamente um reflexo da reapreciação crítica das fórmulas sociopolíticas das comunidades deste período e um 
importante instrumento de investigação que reúne contributos teóricos de enorme interesse e utilidade e casos de estudo tão diversificados como ilustrativos.

O volume inicia-se com um prefácio da autoria de Timothy Earle, no qual o autor, cuja obra no domínio da Antropologia Económica tem influenciado de forma decisiva o pensamento arqueológico sobre o tema da emergência e desenvolvimento da complexidade social, oferece uma breve, mas utilíssima panorâmica da análise e conceptualização do igualitarismo e das sociedades igualitárias no pensamento antropológico, estabelecendo assim um importante pano de fundo teórico para o resto do volume.

Quanto ao corpo do volume propriamente dito, o mesmo inicia-se com duas contribuições que se revestem também elas de um cariz eminentemente teórico, complementando e expandindo assim esse pano de fundo e situando o leitor face ao contexto e abordagem do livro enquanto um todo. Assim, o primeiro capítulo da obra, da autoria de Inés Sastre e Brais X. Currás, explora a historiografia e as diversas vertentes teóricas e conceptuais das análises dedicadas ao igualitarismo e às sociedades igualitárias no âmbito específico da Arqueologia. Já o capítulo seguinte, da autoria de Bill Angelbeck, reflecte especificamente sobre o potencial de uma grelha de leitura anarquista aplicada às sociedades da Idade do Ferro, oferecendo uma interessante resenha do desenvolvimento do pensamento dialéctico no seio da teoria anarquista e uma reflexão de fundo sobre a sua aplicabilidade ao estudo das formas complexas de articulação entre hierarquia e igualitarismo na Idade do Ferro.

Em conjunto, estes dois capítulos constituem um instrumento de trabalho de inegável valor, introduzindo não apenas pistas sobre novas formas de conceber e modelizar as sociedades da Idade do Ferro europeia, mas também ferramentas teóricas e práticas para desenvolver uma releitura crítica dessas sociedades, alcançando visões mais completas, coerentes e matizadas das mesmas.

O terceiro capítulo do volume, da autoria de Stephen A. Dueppen, dedicado às sociedades da Idade do Ferro do Burkina Faso, parte do caso de estudo do sítio de Kirikongo para ilustrar os processos através dos quais as comunidades daquela região preservaram activamente a sua estrutura social não-estratificada e descentralizada, enfatizando assim o carácter do igualitarismo como processo activo e negociado. Ao constituir o único caso de estudo não-europeu incluído neste volume, o estudo de Stephen A. Dueppen reveste-se de um inegável valor acrescido, tanto pelas fontes que maneja - algumas das quais, como a documentação etnográfica, não têm paralelo no contexto do estudo da Idade do Ferro europeia - como pelo seu considerável potencial comparativo.

O restante volume engloba um conjunto de casos de estudo referente a áreas e períodos concretos da Idade do Ferro do continente europeu. Sem grandes surpresas, as llhas Britânicas ocupam um lugar destacado entre esses casos de estudo, facto a que não será alheia a comparativamente longa tradição de desenvolvimento e aplicação de modelos igualitários à Idade do Ferro daqueles territórios (Collis 1994; 2012).

Assim, no Capítulo 5, John Collis oferece uma síntese dos modelos dominantes sobre a estrutura social da Idade do Ferro, com particular ênfase no Sul de Inglaterra e especialmente no emblemático sítio de Danebury. No Capítulo 6, Richard Hingley traça igualmente uma história intelectual dos modelos relativos à estrutura sociopolítica das sociedades da Idade do Ferro do Sul de Inglaterra, contextualizando-os em face das agendas sociopolíticas do presente. No Capítulo 9, David McOmish apresenta uma reflexão sobre os chamados "midden sites" da Idade do Ferro do Sul de Inglaterra, analisando-os à luz de um modelo de relações sociopolíticas fragmentárias, cambiantes e dinâmicas.

Já no Capítulo 10, lan Armit analisa o processo histórico que medeia entre o final da Idade do Bronze e os contactos com o Império Romano nas Terras Baixas escocesas, evidenciando o interesse de uma leitura diacrónica que situe historicamente o desenvolvimento de fórmulas de organização social e política avessas à hierarquização. Finalmente, no Capítulo 14, Niall Sharples analisa o fenómeno dos brochs da Idade do Ferro da Escócia Atlântica à luz do conceito lévi-straussiano de "sociedade de casas" (Lévi-Strauss 1975; cf. González-Ruibal 2006), conceito que se introduz nesta contribuição de forma detalhada e que se aplica de forma convincente àquelas particulares manifestações arqueológicas da Idade do Ferro escocesa.

É particularmente grato notar que a Península lbérica constitui a outra área regional mais bem representada entre os casos de estudo compilados neste volume - a par, de facto, com as Ilhas Britânicas -, facto 
para o qual evidentemente contribuem os trabalhos pioneiros que os próprios editores da obra têm vindo a desenvolver nos últimos anos. Assim, no Capítulo 7, Brais X. Currás e Inés Sastre oferecem uma interessante e estimulante resenha da história do conceito de sociedades segmentares no âmbito da Antropologia, analisando seguidamente a sua aplicabilidade às comunidades da Idade do Ferro utilizando como exemplo a cultura castreja do Noroeste Peninsular. Também César Parcero Oubiña, Xosé-Luís Armada, Samuel Nión e Félix González Insúa dedicam a sua atenção no Capítulo 8 às comunidades castrejas desta região, neste caso recorrendo a uma análise espacial para abordar a diversidade das trajectórias sociais das comunidades do Noroeste entre o final da Idade do Bronze e a Idade do Ferro. Já no Capítulo 13, Alberto Santos Cancelas explora o papel da religião nestas comunidades castrejas, desconstruindo os estereótipos em torno da "ideologia guerreira" céltica, cuja aplicabilidade se restringe a cenários históricos concretos, mais tardios, propondo pelo contrário que as práticas religiosas castrejas contribuíram também para conter e minimizar a hierarquização social durante boa parte da Idade do Ferro.

A representação da Península Ibérica neste volume não se esgota, contudo, nos casos de estudo centrados no Noroeste. Com efeito, no Capítulo 16 Francisco Burillo Mozota e María Pilar Burillo Cuadrado apresentam uma abordagem diacrónica ao desenvolvimento das comunidades da área celtibérica, enfatizando a persistência de formas de organização camponesa numa sociedade tradicionalmente conotada com uma forte hierarquização social. No Capítulo 17, por seu turno, Ignacio Grau-Mira oferece uma leitura alternativa da organização das sociedades ibéricas da fachada oriental da Península Ibérica, abordando distintas ordens de evidências para questionar a igualmente tradicional visão uniformista e hierárquica das comunidades da Idade do Ferro naquela região.

Os casos de estudo britânicos e peninsulares, que constituem quantitativamente o núcleo mais expressivo deste livro, encontram-se não obstante acompanhados e complementados por diversos outros contributos relativos a outras geografias, que ampliam o escopo e alcance comparativo do volume. Assim, o Capítulo 4, da autoria de Ralph Araque González, aborda a questão da estrutura social das comunidades nurágicas da Idade do Bronze sarda, passando em revista os modelos hierárquicos tradicionais e as alternativas mais igualitárias que se têm avançado para analisar o seu peculiar registo arqueológico.

Dentro dessas alternativas, a leitura dos nuraghes sardos não como estruturas de elite, mas como projectos colectivos, emblemáticos da comunidade e produtos de uma cooperação e coordenação não-hierárquica, resulta particularmente sugestiva. Esta nova leitura bem poderia aplicar-se a outros âmbitos e contextos nos quais a inversão de trabalho na construção de monumentos concretos se tem vindo a tomar como evidência incontornável da existência de estruturas sociais hierarquizadas.

No Capítulo 11, dedicado às comunidades da Idade do Ferro do Médio Danúbio, Vladimir D. Mihajlović toca novamente neste ponto no contexto de uma discussão sobre a equação "povoado fortificado = lugar central = hierarquia territorial", concluindo que também nesta região os indícios de uma hierarquização inequívoca são ambíguos, na medida em que o registo arqueológico evidencia antes uma situação complexa que não encaixa de forma fácil nem num modelo hierárquico nem num outro totalmente heterárquico, mas antes numa estrutura sociopolítica que combina elementos de ambos.

Com o capítulo seguinte (Capítulo 12), assinado por marjolin kok, o livro regressa à Europa Ocidental, e concretamente à Holanda, mas também à grelha de leitura anarquista anteriormente introduzida no volume por Bill Angelbeck, oferecendo considerações adicionais sobre a história do pensamento anarquista e ilustrando as suas aplicações na leitura do registo arqueológico através do sugestivo caso de estudo da Idade do Ferro da área de Oer-IJ.

Finalmente, um último contributo, da autoria de John Bintliff (Capítulo 15), introduz nesta discussão a Idade do Ferro grega, porventura um dos tópicos mais estudados e escrutinados no âmbito da investigação sobre a Idade do Ferro no continente europeu e no Mediterrâneo. Neste texto, o autor oferece um interessante resumo das dinâmicas sociais no âmbito grego durante a Idade do Ferro, ilustrando de forma sucinta, mas sugestiva, a diversidade de trajectórias sociopolíticas durante este período, nomeadamente entre Creta e o território grego continental.

Ao longo das quase quatrocentas páginas deste volume, os diversos autores antes enunciados apresentam 
registos arqueológicos muito distintos entre si e ricos de ensinamentos sobre a diversidade e complexidade das fórmulas sociais e políticas do passado, em geral, e da Idade do Ferro em particular. Mas além disso, naquela que é indiscutivelmente uma das grandes mais-valias deste livro, introduzem-nos a uma panóplia de quadros teóricos e conceptuais através dos quais (re-)pensar as sociedades da Idade do Ferro europeia.

Assim, os contributos recolhidos neste volume cujas respectivas bibliografias constituem em si mesmas, diga-se, um utilíssimo instrumento de trabalho - introduzem-nos a quadros conceptuais como (sem pretensões de exaustividade) o Igualitarismo (esp. o Capítulo 1), o Transigualitarismo (Hayden 2001), o Anarquismo (esp. os Capítulos 2 e 12), a Heterarquia (Crumley 1995), a Teoria da Acção Colectiva (De Marrais - Earle 2017), e a modelos como os das Sociedades Camponesas (Wolf 1957; 1982), das Sociedades de Casas (Lévi-Strauss 1975; v. tb. González-Ruibal 2006), das Sociedades Segmentares (esp. o Capítulo 7), das Sociedades Horizontalmente Integradas (McIntosh 1999) e, em geral, das Sociedades Não-Triangulares (Hill 2011), que constituem um importante antídoto para as fórmulas assentes em leituras esquemáticas, simplificadas e muitas vezes automáticas da estrutura social das comunidades da Idade do Ferro.

Definitivamente, o volume Alternative Iron Ages constitui um marco indelével num processo duplo de desconstrução historiográfica e de reconstrução crítica e reflexiva que constitui um dos mais valiosos e estimulantes desenvolvimentos da investigação sobre a Idade do Ferro europeia nos últimos anos, merecendo por isso o devido destaque não só junto dos investigadores que sobre ela trabalham, mas também nas listas de leitura das disciplinas universitárias que a abordam.

\section{Bibliografia}

ARNOLD, B. - GIBSON, D. B. (eds.) (1998) - Celtic Chiefdom, Celtic State.The Evolution of Complex Social Systems in Prehistoric Europe. Cambridge.

COLLIS, J. R. (1994) - Reconstructing Iron Age society. In KRISTIANSEN, K. \& JØRGENSEN, J. (eds) - Europe in the First Millennium B.C.. Sheffield: 31-39.

COLLIS, J. R. (2011) - 'Reconstructing Iron Age Society' revisited. In MOORE, T. \& ARMADA, X.-L. (eds.) - Western Europe in the First Millennium BC: Crossing the Divide. Oxford: 223-241.

CRUMLEY, C. L. (1995) - Heterarchy and the analysis of complex societies. Archeological Papers of the American Anthropological Association, 6 (1): 1-5.

De MARRAIS, E. \& EARLE, T. (2017) - Collective action theory and the dynamics of complex societies. Annual Review of Anthropology, 46: 183-201.

GONZÁLEZ-RUIBAL, A. (2006) - House societies vs. kinship-based societies: An archaeological case from Iron Age Europe. Journal of Anthropological Archaeology, 25 (1): 144-173.

HAYDEN, B. (2001) - The dynamics of wealth and poverty in the transegalitarian societies of Southeast Asia. Antiquity, 75: 571-581.

HILL, J. D. (2001) - How Did British Middle and Late Pre-Roman Iron Age Societies Work (If They Did)? In MOORE, T. \& ARMADA, X.-L. (eds.) - Western Europe in the First Millennium BC: Crossing the Divide. Oxford: 242-263.

LÉVI-STRAUSS, C. (1975) - La Voie des Masques. Paris.

McINTOSH, S. K. (ed.) (1999) - Beyond Chiefdoms: Pathways to Complexity in Africa. Cambridge.

WOLF, E. R. (1957) - Closed corporate peasant communities in Mesoamerica and Central Java. Southwestern Journal of Anthropology, 13: 1-18.

WOLF, E. R. (1982) - Europe and the People Without History. Berkeley.

THURSTON, T. L. (2010) - Bitter Arrows and Generous Gifts: What Was a 'King' in the European Iron Age? In PRICE, T. D. \& FEINMAN, G. M. (eds.) - Pathways to Power New Perspectives on the Emergence of Social Inequality. Nova York: 193-254. 


\section{EDITORIAL POLICY}

Ophiussa - Revista do Centro de Arqueologia da Universidade de Lisboa started in 1996, with the edition of volume 0 . From 2017, this journal is a printed and digital edition of UNIARQ - Centro de Arqueologia da Universidade de Lisboa.

The main objective of this journal is the publication and dissemination of papers of interest, quality and scientific rigor concerning Prehistory and Archeology, mostly from Europe and the Mediterranean basin.

Ophiussa - Revista do Centro de Arqueologia da Universidade de Lisboa will publish an annual volume. From 2018, submitted articles will be subject to a peer-review evaluation process. The submission period will always occur in the first quarter of each year and the edition will occur in the last quarter.

The journal is divided into two sections: scientific articles and bibliographic reviews. Exceptionally, texts of an introductory nature may be accepted, in the context of specific tributes or divulgations, which will not be submitted to peer-review evaluation. Exemptions from this evaluation are also the bibliographic reviews.

All submissions will be considered, in the first instance, by the Editorial Board, regarding its formal content and adequacy in face of the editorial policy and the journal's editing standards. Papers that meet these requirements will subsequently be submitted to a blind peerreview process (minimum of two reviewers). The Scientific Council, constituted by the directors of UNIARQ and external researchers, will follow the editing process.

This stage will be carried out by qualified external researchers, and their feedback will be delivered within a period of no more than two months. The reviewers will carry out the evaluation in an objective manner, in view of the quality and content of the journal; their criticisms, suggestions and comments will be, as far as possible, constructive, respecting the intellectual abilities of the author(s). After receiving the feedback, the author(s) has a maximum period of one month to make the necessary changes and resubmit the work.

Acceptance or refusal of articles will have as sole factors of consideration their originality and scientific quality. The review process is confidential, with the anonymity of the evaluators and authors of the works being ensured, in the latter case up to the date of its publication.

Papers will only be accepted for publication as soon as the peer review process is completed. Texts that are not accepted will be returned to their authors. The content of the works is entirely the responsibility of the author(s) and does not express the position or opinion of the Scientific Council or Editorial Board. The Journal Ophiussa follows the guidelines established by the Commitee on Publication Ethics (COPE, the Ethics Committee Publications): https:// publicationethics.org/
The editorial process will be conducted objectively, impartially and anonymously. Errors or problems detected after publication will be investigated and, if proven, corrections, retractions and / or responses will be published. Contributions submitted for publication must be unpublished. Article submissions can not include any problem of forgery or plagiarism. In order to detect plagiarism, the URKUNDU platform will be used.

Illustrations that are not from the author(s) must indicate their origin. The Scientific Council and Editorial Board assume that the authors have requested and received permission to reproduce these illustrations and, as such, reject the responsibility for the unauthorized use of the illustrations and legal consequences for infringement of intellectual property rights.

It is assumed that all Authors have made a relevant contribution to the reported research and agree with the manuscript submitted. Authors must clearly state any conflicts of interest. Collaborations submitted that directly or indirectly had the financial support of third parties must clearly state these sources of funding.

Texts proposed for publication must be unpublished and should not have been submitted to any other journal or electronic edition. Works written in Portuguese, English, Spanish, Italian and French are accepted.

The publication of texts in Ophiussa - Revista do Centro de Arqueologia da Universidade de Lisboa does not imply the payment of any fee nor does it entitle to any economic remuneration.

This edition immediately and freely provides all of its content, in open access, in order to promote global circulation and exchange of scientific research and knowledge. This publication has a limited printed edition in black and white, which will be distributed free of charge by the most relevant international libraries and institutions, and exchanged with periodicals of the same specialty, which will be integrated in the Library of Faculdade de Letras of Universidade de Lisboa. It also has a digital version, in color, available at address http://ophiussa.letras.ulisboa.pt, where one can consult the entire edition.

For more information contact: ophiussa@letras.ulisboa.pt 
REVISTA DO CENTRO DE ARQUEOLOGIA DA UNIVERSIDADE DE LISBOA

ÍNDICE

O tecno-complexo Acheulense em Portugal:

contribuição para um balanço dos conhecimentos

CARLOS FERREIRA, JOÃO PEDRO CUNHA-RIBEIRO, EDUARDO MÉNDEZ-QUINTAS

Brief overview of zooarchaeological research within the framework

of Middle Palaeolithic subsistence theories

MARIANA NABAIS

A distribuição espacial dos materiais líticos da UE003 do Rodo:

testemunho de reocupações do sítio ao longo do Tardiglaciar?

CRISTINA GAMEIRO, THIERRY AUBRY, BÁRBARA COSTA, SÉRGIO GOMES,

YANN LE JEUNE, CARMEN MANZANO, MAURIZIO ZAMBALDI

O sítio do Neolítico Antigo de Montum de Baixo (Melides - Alentejo Litoral)

63

JOAQUINA SOARES, CARLOS TAVARES DA SILVA, SUSANA DUARTE

A economia alimentar em Chibanes (Setúbal) - horizonte campaniforme

JOÃO LUÍS CARDOSO, CARLOS TAVARES DA SILVA, JOAQUINA SOARES, FILIPE MARTINS

Luto en la cara: ablaciones de duelo en el Mediterráneo Ancestral

ÁLVARO GÓMEZ PEÑA, JOSÉ LUIS ESCACENA CARRASCO

Dois conjuntos anfóricos do Castelo de São Jorge (Lisboa):

Largo de Santa Cruz do Castelo e Pátio José Pedreira

VICTOR FILIPE

A face romana de Santa Olaia (Figueira da Foz, Portugal) -

uma leitura possível a partir da cultura material

RICARDO COSTEIRA DA SILVA, SARA OLIVEIRA ALMEIDA, ISABEL PEREIRA

Cerâmica estampada britânica em Portugal (1780-1920).

Identidade, domesticidade e relações

TÂNIA CASIMIRO, INÊS CASTRO, TIAGO SILVA

Recensões bibliográficas

(TEXTOS: JOÃO LUÍS CARDOSO, ANA CATARINA SOUSA, VICTOR S. GONÇALVES,

FRANCISCO B. GOMES, PEDRO ALBUQUERQUE, LEYRE MORGADO-RONCAL)

Política editorial 